\title{
Letters
}

\section{Apology from CMAJ's interim editor-in-chief on behalf of the CMAJ}

I sincerely apologize on behalf of the CMAJ for my error in publishing the letter by Dr. Sherif Emil, which did not contain appropriate subject matter for publication by the CMAJ and which has disgusted many readers across Canada. I sincerely apologize for the considerable hurt that so many people, including medical colleagues and learners, have experienced from reading the letter. I take full responsibility for the inadequacy of editorial process that led to this error. Furthermore, I should point out that the title of the letter was authored by the CMAJ and was not the responsibility of Dr. Emil.

CMAJ is formally retracting the letter, which will include removal of all text except for the title and author information (https://www.cmaj.ca/ content/193/51/E1936).
The CMAJ's Editorial Advisory Board, on whom some critics have called to account for the letter's publication, are never involved in the selection of articles, including letters, for publication.

CMAJ will always respect and support the right of women to choose to dress as they wish.

Further, CMAJ editors will urgently review the journal's processes for considering, reviewing and publishing submitted letters; we will act to ensure proper rigour through a process that seeks to reduce bias, with necessary checks and balances.

In March 2021, I committed the CMAJ to antiracism (https://www.cmaj.ca/content /193/13/E453), which included commitments to ensuring diverse representation on the editorial team and advisory bodies at the journal. Representation of Canada's Muslim community is currently lacking on our advisory bodies, and I shall seek to remedy this. My March editorial also called on readers to hold me and CMAJ accountable. You have again called on us to do better on tackling bias and structural change at the journal. While it's clear that CMAJ may have lost the trust of many stakeholders this week, I hope that with humility and action we can earn it back.

\section{Kirsten L. Patrick MBBCh MSc}

Interim editor-in-chief, CMAJ

Cite as: CMAJ 2021 December 23;193:

E1935. doi: 10.1503/cmaj.81033

Competing interests: See www.cmaj.ca/site/ misc/cmaj_staff.xhtml.

Content licence: This is an Open Access article distributed in accordance with the terms of the Creative Commons Attribution (CC BY-NC-ND 4.0) licence, which permits use, distribution and reproduction in any medium, provided that the original publication is properly cited, the use is noncommercial (i.e., research or educational use), and no modifications or adaptations are made. See: https://creativecommons.org/ licenses/by-nc-nd/4.0/ 